\title{
Uji Total Plate Count (TPC) Bakteri Pada Minuman Teh Poci Homemade di Gampong Batoh Banda Aceh
}

\author{
Yuni Dewi Safrida ${ }^{1}$, Hardiana $^{2}$, Mauliyana ${ }^{3}$ \\ ${ }^{1,2,3}$ Akademi Analis Farmasi dan Makanan Banda Aceh \\ *Koresponden Email: yunidewi_safrida@yahoo.com
}

Diterima: 1 Maret 2021

Disetujui: 10 Maret 2021

\begin{abstract}
Poci tea is a favorite beverage produced by household industry. Considering its hygienic quality so that it is not contaminated by microbes seems to be an important factor. This study aims to determine the level of microbial contamination in Poci tea produced by household retailers in Batoh, Banda Aceh. This study was conducted at the Pharmacy Laboratory, Academy of Pharmacy and Food Analysts (AKAFARMA) Banda Aceh from 8 to 12 June 2020. The method of this study is a quantitative experimental laboratory with Total Plate Count (TPC). The samples of this study are seven Poci tea obtained from Batoh retailers selected by random sampling. The results showed that the seven Poci teas samples were contaminated microbes, i.e ALMK with a TPC value of $4 \times 103$ colonies / ml, AMK with a TPC value of $4 \times 103$ colonies / ml, HFK with a TPC value of 2x103 colonies / ml, JLM with a TPC value of 3x103 colonies / ml, KUCB with a TPC value of 4x103 colonies / ml, MHFK with a TPC value of 4x103 colonies / ml, and MHZZ with a TPC value of 2x103 colonies / ml. In conclusion, the seven Poci tea samples sold in Batoh have TPC values that are not permitted by the Regulation of the Head of RI POM No. 16 of 2016. Therefore, this poci tea is not recommended for consumption.
\end{abstract}

Keywords: microbial contaminant, poci tea, total plate count, coliform, e. coli.

\section{Abstrak}

Teh poci merupakan minuman favorit hasil produksi rumah tangga yang harus diperhatikan kualitas higienis sehingga tidak tercemar oleh mikroba. Penelitian ini bertujuan untuk mengetahui tingkat cemaran mikroba dalam minuman teh poci produksi rumah tangga yang dijual di Batoh Kota Banda Aceh. Penelitian ini dilaksanakan di Laboratorium Farmasi, Akademi Analis Farmasi dan Makanan (AKAFARMA) Banda Aceh dari Tanggal 8 Juni sampai 12 Juni 2020. Metode yang digunakan adalah eksperimental laboratorium dengan Total Plate Count (TPC). Ketujuh sampel teh poci yang dijual di Batoh Kota Banda Aceh yang dipilih secara acak untuk diuji. Hasil penelitian menunjukkan dari ke tujuh sampel teh poci ini tercemar mikroba, yaitu ALMK dengan nilai TPC $4 \times 10^{3} \mathrm{koloni} / \mathrm{ml}$, AMK dengan nilai TPC $4 \times 10^{3} \mathrm{koloni} / \mathrm{ml}$, HFK dengan nilai TPC $2 \times 10^{3} \mathrm{koloni} / \mathrm{ml}$, JLM dengan nilai TPC $3 \times 10^{3}$ koloni $/ \mathrm{ml}$, KUCB dengan nilai TPC $4 \times 10^{3} \mathrm{koloni} / \mathrm{ml}$, MHFK dengan nilai TPC $4 \times 10^{3} \mathrm{koloni} / \mathrm{ml}$, dan MHZZ dengan nilai TPC $2 \times 10^{3} \mathrm{koloni} / \mathrm{ml}$. Ketujuh sampel teh poci yang dipasarkan di daerah Batoh memiliki nilai TPC yang melebihi ambang batas yang telah ditetapkan oleh Peraturan Kepala BPOM RI Nomor 16 Tahun 2016. Sehingga teh poci ini tidak layak untuk dikonsumsi.

Kata Kunci: cemaran mikroba, teh poci, angka lempeng total, koliform, e. coli.

\section{Pendahuluan}

Camellia sinensis L. Kuntze merupakan tanaman asli Cina dan masuk ke Indonesia sekitar tahun 1684. Di Indonesia Camellia sinensis berkembang secara pesat dan dipasarkan secara komersial. Salah satu minuman olahan yang berasal dari daun dan pucuk daun Camellia sinensis yang dikenal di Indonesia adalah minuman teh. Teh menempati posisi kedua dalam konsumsi diantara semua minuman lainnya. Beberapa minuman teh komersial yang umum dijumpai di pasaran, yaitu teh bubuk, kemasan celup, kemasan kotak atau botol dan sebagainya [1]. Produk minuman teh kemasan dibuat dalam beberapa variasi, seperti teh ekstrak, teh seduh, dan teh celup murni tanpa penambahan gula atau bahan pangan lainnya. Selanjutnya, produk teh yang dipasarkan tersebut harus syarat-syarat kesehatan (SNI) [2]. Salah satu contoh produk minuman teh dalam kemasan siap saji yang tidak memiliki merek dagang yaitu teh poci.

Teh poci adalah jenis minuman siap saji favorit yang banyak dikonsumsi oleh masyarakat. Teh poci merupakan minuman khas wangi melati dalam wadah gelas plastik dan penambahan es batu agar 
terasa dingin dan enak. Umumnya, teh poci menggunakan pemanis dari gula batu. Oleh karena gula baru bertekstur keras maka membutuhkan waktu yang relatif lama untuk melarutkan gula di dalam teh.

Kelebihan teh poci yang menarik minat konsumen adalah kemasannya yang menggunakan wadah plastik, sehingga praktis untuk dibawa kemana saja. Disisi lain, anak-anak juga merupakan konsumen terbesar dari teh poci, di samping rasanya yang enak juga didukung dengan gambar pada lapisan penutup teh yang menarik. Teh berwarna cokelat dengan aroma yang harum serta rasa yang segar membuat teh poci cocok untuk dijadikan minuman menjamu tamu. Namun demikian, karena the poci merupakan produksi rumah tangga (homemade) tidak menutup kemungkinan bahwa teh poci mudah terkontaminasi oleh bakteri, seperti bakteri coliform [3].

Menurut Ref. [4], teh poci merupakan salah satu minuman yang sering terkontaminasi oleh patogen. Hal tersebut cenderung terjadi selama proses pengolahan dan produksinya. Patogen adalah mikroorganisme penyebab penyakit pada manusia apabila tertelan melalui makanan ataupun minuman [5]. Jenis-jenis mikroorganisme patogen, yaitu bakteri, virus, ragi, dan jamur [4].

Pencemaran mikroorganisme seperti bakteri patogen pada teh poci dapat mengakibatkan penyakit saluran pencernaan dengan gejala mual, muntah, hingga diare akut. Bakteri patogen penyebab penyakit saluran pencernaan adalah bakteri coliform. Coliform yang sering ditemukan di dalam minuman kemasan adalah jenis bakteri Escherichia coli. Karenanya, keberadaan E. coli dalam makanan atau air biasanya menandakan kontaminasi feses atau kondisi higienis yang buruk di fasilitas pemrosesan makanan [6]. Faktanya, setiap hari, hampir 1.000 anak meninggal karena penyakit diare terkait air dan sanitasi [7] [8]. Hal ini menjadi menjelaskan E. coli sebagai mikroba indikator untuk memeriksa sampel air yang bertujuan untuk mendeteksi tingkat kontaminasi feses [9]. Untuk mengetahui minuman teh kemasan layak untuk dikonsumsi atau tidak maka perlu dilakukan analisis mikrobiologi pada sampel tersebut [10].

Sejauh ini belum diketahui secara pasti apakah minuman olahan layak untuk dikonsumsi, baik dari segi bahan baku air yang digunakan maupun tingkat kehigienisan alat-alat yang digunakan dalam proses produksi. Jika ditemukan jasad tercemar pada minuman olahan teh poci, maka akan mengindikasikan minuman olahan tersebut tidak layak dikonsumsi. Berdasarkan hal tersebut diperlukan upaya untuk mengetahui kualitas keamanan minuman dengan menggunakan parameter Total Plate Count (TPC) [11]. TPC adalah sebuah metode yang umum digunakan dalam memperkirakan jumlah total mikroorganisme (kapang, ragi, bakteri) dalam suatu bahan [12].

Menurut Permenkes RI No. 416 Tahun 1990 menyatakan bahwa air bersih yang digunakan untuk kebutuhan sehari-hari kualitasnya harus memenuhi syarat-syarat kesehatan, sehingga setelah dimasak dapat diminum. Syarat kesehatan mengenai kualitas air yaitu harus memenuhi persyaratan mikrobiologi, kimia, serta fisika [13]. Sejalan dengan hal tersebut, Peraturan Kepala BPOM RI No. 16 Tahun 2016 mengenai mikroorganisme dalam pangan olahan yaitu nilai TPC maksimum yang diperbolehkan pada minuman jajanan adalah 1x102 koloni/ml dengan perhitungan koloni maksimum 30-300 koloni/ml [14].

Menurut Ref. [15], teh poci yang dijual diseputaran Pasar Raya Padang belum memenuhi standar, baik dalam penyajian maupun kebersihan. Hal tersebut disebabkan air yang digunakan sebagai bahan dasar teh berasal dari depot air minum isi ulang yang masih dipertanyakan kehigienisannya. Ref. [16] melaporkan adanya kontaminasi bakteri E. coli pada makanan serta minuman yang jual bebas oleh pedagang kaki lima di Jakarta. Kasus penyakit terkait air dan makanan ini dilaporkan sebanyak $60 \%$ yang disebabkan oleh proses pengolahan makanan dan minuman dan proses penyajian. Dilaporkan juga oleh tribunnews pada Agustus 2018, bahwa terdapat 32 siswa Madrasah Ibtidaiah Negeri (MIN) Kepatihan, Kabupaten Bojonegoro yang mengalami keracunan dan dibawa ke RS Aisyah Bojonegoro untuk mendapatkan penanganan setelah meminum teh poci. Berdasarkan permasalahan tersebut, maka penting untuk dilakukan penelitian mengenai uji Total Plate Count bakteri pada teh poci yang dijual di Batoh Banda Aceh agar dapat diketahui kelayakan minuman kemasan tersebut untuk dikonsumsi.

\section{Metode Penelitian}

Penelitian ini telah dilaksanakan di Laboratorium Farmasi, Akademi Analis Farmasi dan Makanan (AKAFARMA) Banda Aceh dari Tanggal 8 Juni sampai 12 Juni 2020. Alat yang digunakan dalam penelitian, yaitu cawan petri, beaker glass, tabung reaksi, bunsen, erlenmeyer $500 \mathrm{ml}$, timbangan analitik, gelas ukur $10 \mathrm{ml}$, batang pengaduk, autoclave, inkubator, colony counter, kompor gas, penggaris, spatula, kertas koran/plano, kapas, aluminium foil, dan spidol. Bahan yang digunakan dalam penelitian, yaitu sampel minuman teh poci (Gambar 1), aquades steril, alkohol, serta media Mueller Hinton Agar (MHA). 


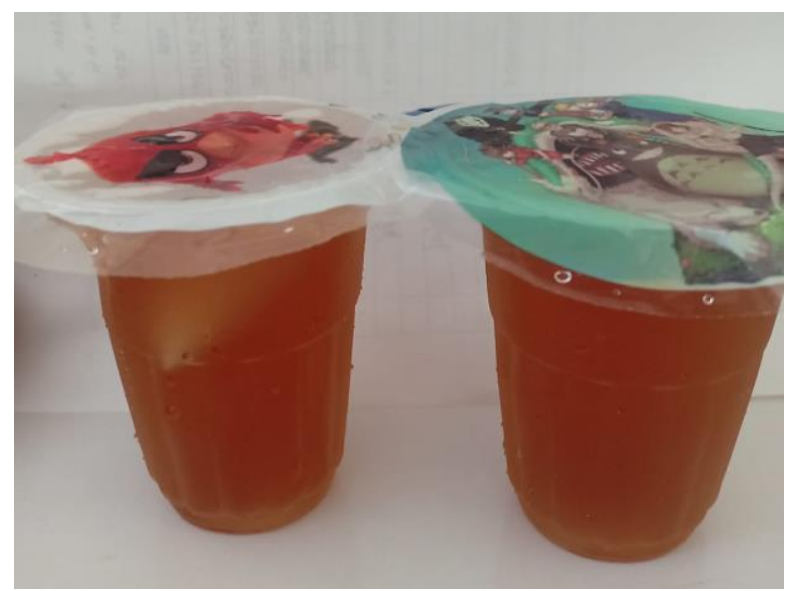

Gambar 1. Minuman teh poci

Sumber: Dokumentasi penelitian, 2020

\section{Metode Penelitian}

Metode yang digunakan pada penelitian ini yaitu eksperimental laboratorium secara kuantitatif dengan metode Total Plate Count (TPC). Sementara itu, teknik pengumpulan sampel menggunakan metode purposive sampling.

\section{Prosedur Kerja}

1. Pembuatan Media Mueller Hinton Agar (MHA)

Sebanyak 59,5 gram Media Mueller Hinton Agar (MHA) ditimbang menggunakan timbangan digital analitik, lalu dimasukkan kedalam erlenmeyer dan ditambahkan aquades steril sebanyak $1750 \mathrm{ml}$ atau 1,75 L. Kemudian dipanaskan sampai larutan mendidih. Selanjutnya, disterilkan selama 15 menit menggunakan autoclave pada suhu $121^{\circ} \mathrm{C}$.

2. Preparasi Sampel

Disiapkan 5 buah tabung reaksi yang telah diisi dengan aquades steril sebanyak $9 \mathrm{ml}$ pada setiap tabungnya. Sampel sebanyak $1 \mathrm{ml}$ dimasukkan kedalam $9 \mathrm{ml}$ larutan aquades steril menggunakan pipet tetes untuk membuat pengenceran $10^{-1}$. Lalu dipindahkan lagi $1 \mathrm{ml}$ suspensi dari pengenceran $10^{-1} \mathrm{ke}$ dalam tabung reaksi yang telah berisi $9 \mathrm{ml}$ aquades steril untuk membuat pengenceran $10^{-2}$. Kemudian, diulangi dengan cara yang sama untuk membuat pengenceran $10^{-3}, 10^{-4}$, sampai $10^{-5}$.

3. Cara Kerja Total Plate Count (TPC)

Dituangkan media Mueller Hinton Agar (MHA) sebanyak 15 atau $20 \mathrm{ml}$ kedalam cawan petri yang sudah didinginkan. Menggunakan pipet tetes steril diambil sebanyak $1 \mathrm{ml}$ dari setiap pengenceran mulai dari $10^{-1}$ sampai $10^{-5}$, lalu dimasukkan kedalam cawan petri steril. Agar suspensi tersebar merata di dalam cawan maka cawan petri harus digoyang membentuk angka delapan dengan segera mungkin. Dilakukan duplo untuk setiap pengenceran. Selanjutnya, diinkubasi dengan kisaran waktu 24-48 jam dengan suhu $37^{\circ} \mathrm{C}$. Setelah itu diamati dan dihitung jumlah koloni yang tumbuh pada media dengan cara membalik cawan petri.

\section{Analisis Data}

Metode penghitungan TPC terdiri dari pengenceran sampel dengan larutan salin steril atau buffer fosfat hingga bakteri menjadi encer agar dapat dihitung secara akurat. Artinya, lempeng terakhir dalam rangkaian harus berkisar antara 30 dan 300 koloni. Jumlah koloni dibawah 30 tidak dapat diterima karena alasan statistik (terlalu sedikit mungkin tidak mewakili sampel), dan lebih dari 300 koloni pada cawan dianggap terlalu berdekatan satu sama lain, sehingga sulit dihitung sebagai unit koloni yang berbeda (CFU)..

Tabel 1. Rancangan data pengamatan sampel

\begin{tabular}{cccc}
\hline Kode & \multicolumn{3}{c}{ Jumlah koloni (Kol/ml) } \\
Sampel & Pengenceran & Cawan 1 Cawan 2 & TPC \\
& & & \\
\hline \multirow{3}{*}{ A } & $10^{-1}$ & & \\
& $10^{-2}$ & \\
& $10^{-3}$ & \\
& $10^{-4}$ & \\
& $10^{-5}$ & \\
\hline
\end{tabular}

Sumber: Rancangan penelitian, 2020. 
Total koloni yang diperoleh dari pengamatan, lalu dibandingkan dengan nilai persyaratan Peraturan Kepala BPOM RI Nomor 16 Tahun 2016. Syarat TPC minuman teh poci dari hasil pengamatan akan disajikan dalam bentuk tabel seperti pada Tabel 1.

5. Perhitungan Koloni

Perhitungan TPC dilihat pada pengenceran terkecil dengan jumlah koloni yang paling sedikit, dapat dihitung dengan rumus:

$$
\mathrm{N}=\frac{\Sigma \mathrm{C}}{([(1 \times \mathrm{n} 1)+(0,1 \times \mathrm{n} 2)] \times(\mathrm{d}))}
$$

Keterangan:

$\mathrm{N}=$ Jumlah koloni sampel $(\mathrm{Kol} / \mathrm{ml})$

$\Sigma \mathrm{C}=$ Jumlah koloni yang dihitung pada seluruh cawan

$\mathrm{n} 1=$ Jumlah cawan pada pengenceran pertama yang dihitung

$\mathrm{n} 2=$ Jumlah cawan pada pengenceran kedua yang dihitung

$\mathrm{d} \quad=$ Pengenceran pertama yang dihitung

\section{Hasil dan Pembahasan}

Hasil perhitungan Total Plate Count (TPC) bakteri dalam minuman teh poci homemade yang dijual di Gampong Batoh Banda Aceh disajikan pada Tabel 2.

Tabel 2. Data hasil perhitungan jumlah koloni dan nilai TPC dalam minuman teh poci

\begin{tabular}{|c|c|c|c|c|}
\hline \multirow{2}{*}{ Kode Sampel } & \multirow{2}{*}{ Pengenceran } & \multicolumn{2}{|c|}{ Jumlah Koloni (Kol/ml) } & \multirow{2}{*}{$\begin{array}{c}\text { TPC } \\
(\mathrm{Kol} / \mathrm{ml})\end{array}$} \\
\hline & & Cawan 1 & Cawan 2 & \\
\hline \multirow{5}{*}{ ALMK } & $10^{-1}$ & 75 & 166 & \multirow{5}{*}{$4 \times 10^{3}$} \\
\hline & $10^{-2}$ & 145 & 94 & \\
\hline & $10^{-3}$ & 73 & 100 & \\
\hline & $10^{-4}$ & 107 & 33 & \\
\hline & $10^{-5}$ & 67 & 105 & \\
\hline \multirow{5}{*}{ AMK } & $10^{-1}$ & 36 & 97 & \multirow{5}{*}{$3 \times 10^{3}$} \\
\hline & $10^{-2}$ & 80 & 130 & \\
\hline & $10^{-3}$ & 70 & 51 & \\
\hline & $10^{-4}$ & 90 & 83 & \\
\hline & $10^{-5}$ & 55 & 100 & \\
\hline \multirow{5}{*}{ HFK } & $10^{-1}$ & 50 & TBUD & \multirow{5}{*}{$2 \times 10^{3}$} \\
\hline & $10^{-2}$ & 65 & TBUD & \\
\hline & $10^{-3}$ & TBUD & TBUD & \\
\hline & $10^{-4}$ & 69 & 62 & \\
\hline & $10^{-5}$ & 33 & TBUD & \\
\hline \multirow{5}{*}{ JLM } & $10^{-1}$ & 95 & 65 & \multirow{5}{*}{$3 \times 10^{3}$} \\
\hline & $10^{-2}$ & 76 & 107 & \\
\hline & $10^{-3}$ & 220 & TBUD & \\
\hline & $10^{-4}$ & TBUD & TBUD & \\
\hline & $10^{-5}$ & 126 & TBUD & \\
\hline \multirow{5}{*}{ KUCB } & $10^{-1}$ & 85 & 107 & \multirow{5}{*}{$4 \times 10^{3}$} \\
\hline & $10^{-2}$ & 37 & 36 & \\
\hline & $10^{-3}$ & 100 & 245 & \\
\hline & $10^{-4}$ & 170 & 74 & \\
\hline & $10^{-5}$ & 127 & 44 & \\
\hline \multirow{5}{*}{ MHFK } & $10^{-1}$ & 190 & TBUD & \multirow{5}{*}{$4 \times 10^{3}$} \\
\hline & $10^{-2}$ & 255 & TBUD & \\
\hline & $10^{-3}$ & TBUD & TBUD & \\
\hline & $10^{-4}$ & TBUD & TBUD & \\
\hline & $10^{-5}$ & TBUD & TBUD & \\
\hline \multirow{5}{*}{ MHZZ } & $10^{-1}$ & 271 & 92 & \multirow{5}{*}{$2 \times 10^{3}$} \\
\hline & $10^{-2}$ & TBUD & 87 & \\
\hline & $10^{-3}$ & TBUD & TBUD & \\
\hline & $10^{-4}$ & TBUD & 45 & \\
\hline & $10^{-5}$ & 34 & TBUD & \\
\hline
\end{tabular}

Sumber: Data penelitian, 2020 
Berdasarkan Tabel 2 terlihat bahwa hasil perhitungan Total Plate Count (TPC) pada sampel ALMK, KUCB, dan MHFK yaitu sebanyak 4x103 kol/ml. Sedangkan pada sampel HFK dan MHZZ didapatkan hasil perhitungan koloni secara TPC yaitu 2x103 kol/ml. Pada sampel JLM dan AMK didapatkan hasil perhitungan koloni yaitu $3 \times 103 \mathrm{kol} / \mathrm{ml}$. Berdasarkan data hasil uji Total Plate Count (TPC) bakteri pada minuman teh poci tersebut, dapat diasumsikan bahwa ketujuh sampel tersebut tercemar mikroba dan tidak memenuhi syarat kesehatan karena nilai TPC nya melebihi ambang batas yang telah ditetapkan oleh Kepala BPOM RI Nomor 16 Tahun 2016.

Hal yang sesuai dilaporkan oleh Ref. [15], bahwa dari 13 sampel teh poci yang diperoleh dari pegadang yang berjualan di sepanjang Jalan Pasar Raya menunjukkan seluruh sampel yang diperiksa tersebut mengandung bakteri coliform. Hal yang sama dilaporkan oleh Ref. [17], dari sampel minuman teh kemasan yang diteliti ditemukan hasil positif Escherichia coli dengan nilai koliform melebihi standar yang disyaratkan. Sehingga dapat diasumsikan bahwa minuman teh kemasan tersebut tidak layak untuk dikonsumsi. Adapun hasil pengamatan pertumbuhan koloni bakteri E. coli pada media MHA dapat dilihat pada Gambar 2.

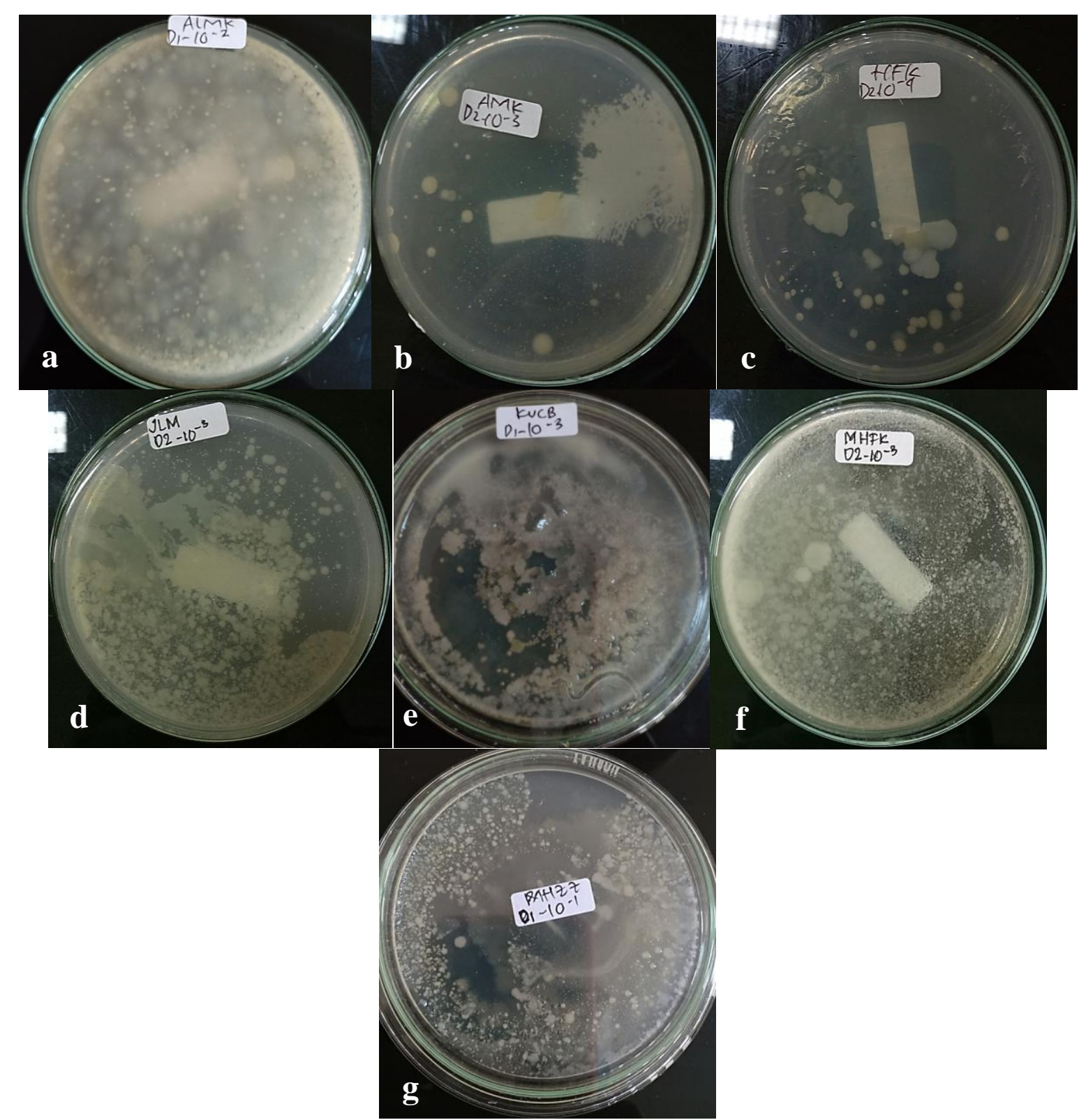

Gambar 2. (a) ALMK pengenceran $10^{-2}$; (b) AMK pengenceran $10^{-3}$; (c) HFK pengenceran $10^{-4}$; (d) JLM pengenceran $10^{-3}$; (e) KUCB pengenceran $10^{-3}$; (f) MHFK pengenceran $10^{-3}$; dan (e) MHZZ pengenceran $10^{-1}$.

Sumber: Dokumentasi penelitian, 2020 
Berdasarkan 7 sampel pada Gambar 2 menunjukkan bahwa koloni yang berhasil tumbuh pada media MHA berasal dari pengenceran yang berbeda-beda. Cawan yang memiliki 30-300 koloni dipilih karena kisaran ini dianggap signifikan secara statistik. Jika ada cawan yang memiliki koloni kurang dari 30 koloni menandakan adanya kesalahan kecil dalam teknik pengenceran. Seperti yang dilaporkan oleh Ref. [18] [19] [20] [21] cawan dengan kisaran 25-250 atau 30-300 koloni per cawan agar (100 $\mu 1$ sampel) ditetapkan sebagai CFU yang dapat diterima untuk penghitungan yang akurat.

Menurut Ref. [22] bakteri coliform dapat menyebar melalui air dan material yang terkontaminasi. Jika ditemukan bakteri coliform pada makanan dan minuman, hal ini menandakan bahwa makanan dan minuman tersebut telah terkontaminasi oleh kotoran manusia secara langsung maupun tidak. Terdapatnya bakteri coliform dalam air minum menandakan adanya bakteri patogen lain. Selain menyebabkan diare, bakteri ini juga bisa menyebabkan demam dan gagal ginjal. [23] Keberadaan E. coli dalam makanan atau air tidak secara langsung menunjukkan bahwa mikroorganisme patogen ada di dalam sampel, tetapi hal ini menunjukkan bahwa terdapat risiko yang lebih tinggi dari keberadaan bakteri yang ditularkan melalui tinja, Oleh karena itu, E. coli banyak digunakan sebagai organisme indikator untuk mengidentifikasi sampel makanan dan air yang mungkin mengandung tingkat kontaminasi tinja yang tidak dapat diterima.

\section{Kesimpulan}

Uji Total Plate Count (TPC) bakteri pada minuman teh poci menunjukkan hasil, yaitu sampel ALMK, KUCB, dan MHFK dengan nilai TPC 4x103kol $/ \mathrm{ml}$. Sampel HFK dan MHZZ dengan nilai TPC $2 \times 103 \mathrm{kol} / \mathrm{ml}$. Sementara, sampel JLM dan AMK dengan nilai TPC yaitu 3x103 kol/ml. Berdasarkan data tersebut dapat diasumsikan bahwa ketujuh sampel tersebut tercemar mikroba dan tidak memenuhi syarat karena melebihi ambang batas dengan Ketentuan Peraturan Kepala BPOM RI Nomor 16 Tahun 2016 mengenai Kriteria Mikrobiologi Dalam Pangan Olahan, bahwa syarat TPC minuman teh dalam kemasan yaitu $1 \times 102 \mathrm{kol} / \mathrm{ml}$, sehingga tidak layak untuk dikonsumsi.

\section{Singkatan \\ $A L M K$ \\ $K U C B$ \\ $M H F K$ \\ $H F K$ \\ $M H Z Z$ \\ $J L M$ \\ $A M K$}

\author{
AMD Dusun Lampuuk Madinah Kue \\ Kampus Unmuha Dusun Cot Baku \\ M. Hasan Flamboyan Kue \\ Hasan Fajar Kue \\ M. Hasan Zam-Zam Kue \\ Jl. Lamdom \\ AMD Mentari Kue
}

\section{Referensi}

[1] S. A. Puspita, A. Karya, "Rebranding Pencitraan Sarana Perangkat Minum Teh Poci Tegal Sebagai Bentuk Pengembangan Budaya Minum Teh Tradisional Khas Tegal," J. Tingkat Sarjana Seni rupa dan Desain, 1 : hal. 1-2, 2012.

[2] S.R. Yani, 2012, Analisis Bakteri Salmonella Sp. dan E. coli Pada Minuman Teh Dalam Kemasan Yang Di jual Di sekolah Muhammadiyah Di Jalan Tanjung sari Medan, J. Kesehatan Online Helvetia, Medan, [Diakses Tanggal 20 Agustus 2020].

[3] I. Nurwah, E. Kumalasari, S. Musiam, "Analisis Kuantitatif Bakteri Coliform Pada Teh Poci Olahan Yang Dijual Di Wilayah Banjarmasin Utara Dengan Metode Most Probable Number (MPN)," Akademi Farmasi ISFI, Banjarmasin, 2015.

[4] Yunaenah, Kontaminasi E. coli Pada Makanan Jajanan Di Kantin Sekolah Dasar, FKM UI, Jakarta Pusat, 2009.

[5] Liise-anne Pirofski and Arturo Casadevall, "Q\&A: What is a pathogen? A question that begs the point," Pirofski and Casadevall BMC Biology, 10:6, 2012.

[6] S. T. Odonkor, J. K. Ampofo, "Escherichia coli as an indicator of bacteriological quality of water: an overview," Microbiology Research, vol. 4, no. 1, p. 2, 2013.

[7] E. Bisung, S. Dickin, "Concept mapping: engaging stakeholders to identify factors that contribute to empowerment in the water and sanitation sector in West Africa," SSM-Population Health, vol. 9, Article ID 100490, 2019.

[8] F. M. Gimelli, J. J. Bos, B. C. Rogers, "Fostering equity and wellbeing through water: a reinterpretation of the goal of securing access," World Development, vol. 104, pp. 1-9, 2018. 
[9] R. G. Price, D. Wildeboer, "E. coli as an indicator of contamination and health risk in environmental waters in Escherichia coli-Recent Advances on Physiology," Pathogenesis and Biotechnological Applications, IntechOpen, London, UK, 2017.

[10] Badan Pengawas Obat dan Makanan Republik Indonesia (BPOM), Pengujian Mikrobiologi Pangan, Info Pom, Jakarta, Vol. 9 (2), 2009.

[11] I. Supardi, Sukamto, Mikrobiologi Dalam Pengolahan dan Pengolahan Pangan, Penerbit alumni, Bandung, 1999.

[12] F. Arifan, S. Winarni, Wahyuningsih, I. Pudjihastuti, R.T. D. Wisnu Broto, "Total Plate Count (TPC) Analysis of Processed Ginger on Tlogowungu Tourism Village," Advances in Engineering Research, vol. 167, 2019.

[13] Peraturan Menteri Kesehatan Republik Indonesia (PERMENKES R.I), Daftar Persyaratan Kualitas Air Bersih, No: 416/Menkes/Per/IX/1990.

[14] Peraturan Kepala Badan Pengawas Obat dan Makanan Republik Indonesia (BPOM). 2016. Tentang Kriteria Mikrobiologi Dalam Bahan Pangan Olahan: Jakarta. NO. 16. Tanggal 24 Mei 2016.

[15] R. Rasyid, "Uji Kualitas Mikrobiologis Minuman Teh Poci Yang Dijual Pedagang Kaki Lima Dipasar Raya Padang," J. UNAND, Padang, 2015.

[16] I. M. Djaja, "Kontaminasi E. coli Pada Makanan Dari Tiga Jenis Tempat Pengelolaan Makanan (TPM)," Makara, Kesehatan, Jakarta Selatan, vol. 12 (1): 36-41, 2008.

[17] Anna Yuliana, Saeful Amin, "Analisis Mikrobiologi Minuman Teh Kemasan Berdasarkan Nilai Apm Koliform," J. Kesehatan Bakti Tunas Husada, vol.15 (1), 2016

[18] J. W. Messer, C. H. Johnson, Total viable counts, Pour plate technique, In: R. K. Robinson, C. A. Batt, P.D. Patel, editors. vol. 3. Academic Press; London: 2000. pp. 2154-2158. (Encyclopedia of Food Microbiology).

[19] P. Thomas, A. C. Sekhar, M. M. Mujawar, "Non-recovery of varying proportions of viable bacteria during spread-plating governed by the extent of spreader usage and proposal for an alternate spotting-spreading approach to maximize the CFU," J. Appl. Microbiol., 113: 339-350, 2012.

[20] P. Thomas, M. M. Mujawar, A. C. Sekhar, R. Upreti, "Physical impaction injury effects on bacterial cells during spread plating influenced by cell characteristics of the organisms," J. Appl. Microbiol, 116: 911-922, 2014.

[21] Wise, K. Preparing spread-plate protocols 2006; http://www.microbelibrary.org/library/laboratorytest/3085-preparing-spread-plates-protocols. (Created: 09 October 2006; last update: 22 July 2013; Accessed on Februari, 2021).

[22] A. H. Prasetyo, "Hubungan Antara Praktik Higiene Penjamah Dengan Keberadaan Coliform Pada Cincau Hitam Yang Dijual Di Lingkungan Kampus Universitas Muhammadiyah Surakarta," 1-11, 2016.

[23] P. João, S. Cabral, "Water Microbiology: Bacterial Pathogens and Water," Int. J. Environ. Res. Public Health, 7(10), pp. 3657-3703, 2010. 